\title{
ANALISIS POSISI BERSAING UNTUK MENENTUKAN \\ STRATEGI PEMASARAN UMKM DI KOTA MALANG
}

\author{
Yayuk Sri Rahayu \\ Jurusan Manajemen UIN Maulana Malik Ibrahim Malang \\ Jl. Gajayana 50 Malang \\ Email: ysrais77@yahoo.com
}

\begin{abstract}
This research aimed to find competitive position and to determine marketing strategic based on competitive position of producer "kripik tempe" at Sanan Kota Malang. Number of responden are thirty companies or $11 \%$ of population and the sampling method is purposive sampling. The variables consist of sales, production, price, equity, period of business, and employee. Cluster analysis was used to answer the aim of this research. The result shows competitive position of the produser "kripik tempe" shared in four cluster are: first cluster named market leader consist of one company, second cluster named market nicher consist of thirteen companies, third cluster named market challenger consist of six companies, and the last cluster named market follower consist of ten companies. Based on this cluster, the company that produce "kripik tempe" can determine dan implement marketing strategic according each competitive position.
\end{abstract}

Keywords: Posisi Bersaing, Strategi Pemasaran, UMKM

Usaha Mikro Kecil dan Menengah (UMKM) merupakan salah satu sektor usaha yang memberikan sumbangan besar bagi perekonomian terutama dalam penyerapan tenaga kerja. Kontribusi UMKM dalam penyerapan tenaga kerja mencapai 99,45\% (Ikhsan, 2004). Badan Pusat Statistik (BPS) Jawa Timur mencatat adanya kenaikan penyerapan tenaga kerja di sektor industri kecil sebesar 4,58\% dari jumlah pekerja di Jawa Timur pada Agustus 2011 yang mencapai 19,76 juta. Karena besarnya kontribusi UMKM tersebut maka kelangsungan hidup UMKM tetap harus terjaga. Namun banyak UMKM yang tidak mampu mempertahankan eksistensinya di pasar karena persaingan yang sangat ketat baik dengan sesama UMKM maupun perusahaan besar. UMKM dituntut mempunyai daya saing tinggi agar mampu bertahan di tengah persaingan bisnis. Hal ini dapat dilakukan dengan menerapkan konsep pemasaran bahwa perusahaan mendapat keunggulan bersaing dengan memuaskan keinginan konsumen sasaran lebih baik dari yang dilakukan pesaing 
(Tjiptono, 2001). Pada dasarnya terdapat keterkaitan antara posisi bersaing dengan strategi bisnis, di mana setiap perusahaan menempati posisi bersaing yang berbedabeda. Untuk itu setiap perusahaan harus mengetahui posisi bersaing masingmasing sehingga dapat menentukan strategi pemasaran yang tepat. Badan Pusat statistik (BPS) menentukan karakteristik usaha mikro yaitu memiliki jumlah tenaga kerja berkisar antara 1-4 orang dan usaha kecil memiliki tenaga kerja berkisar antara 5-19 orang.

Dewi (2001) melakukan penelitian mengenai penentuan posisi bersaing poliklinik PMI di Bogor. Penelitian yang ditujukan untuk menganalisis penentuan posisi bersaing ini, menggunakan rancangan penelitian deskriptif analitik dengan pendekatan kualitatif dan kuantitatif. Hasil penelitian menunjukkan bahwa karakteristik pelanggan Poliklinik Spesialis RSU PMI Bogor terbanyak berasal dari kotamadya Bogor, mayoritas kelompok usia produktif dari kelas menengah bawah dengan pendidikan menengah dan pekerjaan pegawai negeri. Karakteristik pelanggan ini menjadi dasar persepsi mengenai posisi poliklinik itu sendiri dan posisi pesaing. Berdasar persepsi pelanggan disimpulkan posisi poliklinik ini dengan pelayanan yang baik dan terjangkau.

Arifin (2000) meneliti tentang analisis posisi bersaing untuk menentukan strategi pemasaran Perumahan ekslusif Puri Ayodya di kawasan kota Semarang. Hasil analisis SWOT yang menggunakan analisis TOWS Matrix menunjukkan bahwa setelah dicari kaitan antar faktor yang saling mendukung didapatkan strategi generik terpilih. Strategi generik yang direkomendasikan bagi PT Ayodya Puri Nugraha adalah melakukan strategi diferensiasi yang implementasinya meliputi posisi produk, bauran pemasaran dan proses.

Sedangkan penelitian mengenai UMKM juga telah banyak dilakukan diantaranya Setyawan (2010) melakukan penelitian mengenai penentuan prioritas daya saing UMKM dengan rerangka Value Chain Analysis. Penelitian ini dilakukan pada UMKM logam dan komponen otomotif Kabupaten Purbalingga. Data yang dikumpulkan dengan metode FGD (Focus Group Discussion) dan wawancara selanjutnya diolah dengan menggunakan alat analisis AHP. Hasilnya menunjukkan bahwa dari 7 sumber daya saing yang disusun dari model Value Chain UMKM logam dan komponen otomotif yaitu teknologi, sumber daya manusia, pasar, 
kewirausahaan, bahan baku, infrastruktur, dan kondisi ekonomi daerah; ternyata hanya ada tiga daya saing yang layak menjadi prioritas untuk dikembangkan. Ketiga daya saing tersebut adalah teknologi, sumber daya manusia, dan pasar.

Industri kripik tempe di Desa Sanan Malang yang merupakan bagian dari UMKM mengalami perkembangan yang cukup baik. Hingga kini berjumlah kurang lebih 386 pengrajin dari total penduduk yang ada di Desa Sanan. 272 pengrajin dari 386 pengrajin tersebut tergabung dalam wadah koperasi produsen kripik tempe Sanan. Bahkan saat ini Sanan sudah menjadi sentra industri kecil penghasil kripik tempe dan menjadi salah satu produk unggulan Kota Malang. Namun dalam perjalanannya UMKM ini banyak mengalami masalah antara lain banyaknya pesaing yang terus masuk dalam bisnis ini. Hal ini mengakibatkan persaingan yang semakin ketat sehingga para pelaku atau produsen kripik tempe harus dapat menentukan strategi untuk dapat memenangkan persaingan. Strategi pemasaran yang tepat dapat dirumuskan jika perusahaan mampu mengidentifikasi posisi bersaingnya. Posisi bersaing terdiri dari pemimpin pasar (market leader), penantang pasar (market challenger), pengikut pasar (market follower), dan penceruk pasar (market nicher).

Mengingat pentingnya penentuan strategi pemasaran berdasarkan posisi bersaing maka rumusan masalah dalam penelitian ini adalah "Bagaimana posisi bersaing dan penetapan strategi pemasaran berdasarkan posisi bersaing produsen kripik tempe di Sanan Kota Malang?"

\section{Posisi Bersaing}

Perusahaan-perusahaan yang bersaing pada pasar sasaran yang sama, pada waktu tertentu mempunyai sasaran dan sumber daya yang berbeda. Sebagian perusahaan mempunyai banyak sumber daya sedangkan yang lain tidak, sebagian merupakan perusahaan yang sudah tua dan mapan sedangkan yang lain masih baru, dan sebagainya. Perusahaan menempati posisi bersaing yang berbeda-beda dalam satu pasar sasaran. Posisi bersaing yang didasarkan pada peran yang dimainkan perusahaan dalam pasar sasaran dibagi menjadi empat (Kotler \& Amstrong, 2001), yaitu : 1) Pemimpin pasar (Market leader). Perusahaan dalam suatu industri dengan pangsa pasar terbesar, perusahaan ini biasanya memimpin perusahaan lain dalam perubahan harga, pengenalan produk baru, cakupan 
distribusi, dan intensitas promosi. 2) Penantang pasar (Market challenger) Perusahaan peringkat kedua dalam suatu industri yang sedang berjuang keras untuk meningkatkan pangsa pasarnya. 3) Pengikut pasar (Market follower). Perusahaan peringkat kedua dalam suatu industri yang ingin mempertahankan pangsa pasarnya tanpa mengganggu keseimbangan. 4) Perelung pasar (Market nicher). Perusahaan dalam suatu industri yang melayani segmen kecil yang dilupakan atau diabaikan perusahaan lain.

Fandy Tjiptono (2001) membagi posisi bersaing perusahaan dan karakteristiknya sebagai berikut : Pertama, Pemimpin pasar (Market leader) adalah yang memiliki pangsa pasar yang terbesar (40\%) dalam pasar produk yang relevan, lebih unggul dari perusahaan lain dalam hal pengenalan produk baru, cakupan distribusi, dan intensitas promosi, dan Merupakan pusat orientasi para pesaing (diserang, ditiru, atau dijauhi).

Kedua, Penantang pasar (Market challenger) adalah yang memiliki pangsa pasar $30 \%$, selalu berusaha untuk mencari kelemahan pemimpin pasar dan menyerangnya baik secara langsung maupun tidak langsung, memusatkan upaya mereka pada tindakan mengambil alih perusahaan-perusahaan yang lemah.

Ketiga, Pengikut pasar (Market follower) adalah pedagang yang selalu mencoba untuk menonjolkan ciri khasnya kepada pasar sasaran seperti lokasi, pelayanan, keunggulan produk, dan sebagainya, memilih untuk meniru produk atau strategi pemimpin pasar dan penantang pasar daripada menyerang mereka, biasanya memperoleh laba yang tinggi karena tidak menanggung beban pengeluaran yang besar untuk inovasi. Dan keempat, Perelung pasar (Market nicher) pedagang yang biasanya berspesialisasi secara geografis, merupakan perusahaan yang daya beli dan ukurannya cukup besar agar dapat menguntungkan, memiliki potensi untuk berkembang. 
Shimaguchi (2006) mengemukakan Matriks Posisi Bersaing (Competitive Position Matrix) sebagai berikut :

\begin{tabular}{|c|c|c|c|}
\hline \multicolumn{2}{|c|}{$\begin{array}{c}\text { Relative Position of Managerial } \\
\text { Resources }\end{array}$} & Large & Quantity \\
\cline { 2 - 4 } & High & LEADER & NICHER \\
\hline \multirow{2}{*}{ Quality } & Low & CHALLENGER & FOLLOWER \\
\cline { 2 - 4 } & &
\end{tabular}

Sumber : Shimaguchi, 2006

Quantitative managerial resources terdiri dari jumlah penjualan, kekuatan modal, kapasitas produksi, dan sebagainya. Sedangkan qualitative managerial resources terdiri dari kekuatan merek, pemasaran, teknologi, kepemimpinan, dan lain-lain. Hasil dari mapping inilah yang digunakan sebagai dasar penentuan strategi bersaing bagi masing-masing perusahaan.

\section{Strategi Bersaing}

Setelah perusahaan mengetahui posisi bersaingnya maka selanjutnya adalah menentukan strategi bersaing atau strategi pemasaran. Strategi pemasaran berdasarkan posisi bersaing (Tjiptono, 2001) antara lain :

Pertama, Pemimpin pasar (Market leader) peranannya yaitu; a)mengembangkan pasar keseluruhan dapat dilakukan dengan mencari pemakai baru, mencari kegunaan baru, penggunaan yang lebih banyak (lebih sering), b)Melindungi pangsa pasar dapat dilakukan dengan pertahanan posisi, pertahanan samping, pertahanan aktif mendahului, pertahanan serang balik, pertahanan bergerak, dan pertahanan penciutan, dan c)Memperluas pangsa pasar dapat dilakukan dengan keunggulan operasional, kepemimpinan produk, dan keakraban dengan pelanggan.

Kedua, Penantang pasar (Market challenger) akan melakukan Serangan dari depan, serangan mengepung, serangan menyamping, serangan lintas, serangan gerilya

Strategi-strategi menyerang di atas sangat luas sifatnya. Berikut ini adalah beberapa strategi serangan yang spesifik bagi penantang pasar (Kotler \& Keller, 
2007) ; Strategi pemotongan harga, strategi produk murah, strategi produk prestise, strategi pengembangbiakan produk, strategi inovasi produk, strategi penyempurnaan layanan, strategi inovasi distribusi, strategi penekanan biaya produksi, dan promosi yang intensif

Ketiga, Pengikut pasar (Market follower) melakukan kegiatan seperti a) Cloner yaitu meniru dan menyamai segmen pasar dan bauran pemasaran pemimpin pasar.b) Imitiator yaitu membuat beberapa differensiasi namun tetap meniru pemimpin pasar dalam hal pembaruan pasar dan bauran pemasaran. c) Adapter yaitu mencontoh produk-produk pemimpin pasar, memproduksinya namun dengan improvisasi.

Keempat, Perelung pasar (Market nicher)

Gagasan pokok dalam menggarap ceruk pasar adalah spesialisasi antara lain spesialis pemakai akhir, tingkat vertikal, ukuran pelanggan, pelanggan tertentu, geografis, produk atau lini produk, sifat (karakteristik) produk, pesanan, kualitas atau harga, jasa, dan saluran distribusi.

Untuk mempersiapkan strategi pemasaran yang efektif perusahaan harus memperhatikan pesaing dan pelanggannya. Perusahaan harus terus menganalisis pesaing dan mengembangkan strategi pemasaran bersaing yang mampu melawan pesaing secara efektif dan memberi keunggulan bersaing. Analisis pesaing pertamatama melibatkan pengidentifikasian pesaing utama perusahaan. Kemudian menilai sasaran, strategi, kekuatan dan kelemahan, serta pola reaksi pesaing. Dengan menggunakan informasi ini dan ditambah dengan pengetahuan tentang posisi bersaing, perusahaan dapat memilih pesaing yang akan diserang atau dihindari.

\section{METODE PENELITIAN}

\section{Lokasi penelitian}

Penelitian ini dilaksanakan pada usaha mikro dan kecil (UMK) kripik tempe di Dusun Sanan Kelurahan Purwantoro Kecamatan Blimbing Kota Malang. Alasan memilih UMK kripik tempe Sanan Kelurahan Purwantoro Kecamatan Blimbing Kota Malang dikarenakan UMK kripik tempe Sanan merupakan sentra industri makanan olahan yang paling di unggulkan di Kota Malang dan paling banyak dikenal oleh masyarakat. 


\section{Jenis penelitian}

Penelitian ini adalah penelitian kuantitatif deskriptif yaitu suatu penelitian yang bertujuan untuk memberikan gambaran atau lukisan secara sistematis, faktual, dan akurat mengenai fenomena yang diselidiki (Hasan, 2003). Macam penelitian adalah studi kasus yang bertujuan untuk memberikan gambaran secara mendetail tentang latar belakang, sifat-sifat, serta karakter-karakter yang khas dari kasus, individu, kelompok, institusi, atau masyarakat (Masyhuri, 2006). Penelitian ini menjelaskan atau menggambarkan data hasil penelitian dengan diawali teori-teori kemudian mengemukakan fakta atau kenyataan yang bersifat khusus mengenai posisi dan strategi bersaing.

\section{Pengumpulan data}

Data yang digunakan terdiri dari data primer dan data sekunder, yaitu :

1. Data primer diperoleh langsung dari sumbernya dengan metode wawancara dengan para produsen kripik tempe yang menjadi sampel penelitian.

2. Data sekunder diperoleh dari BPS Kota Malang dan Kementerian Koperasi dan UKM Kota Malang.

\section{Populasi dan Sampel}

Populasi menurut Arikunto (2006) adalah keseluruhan subyek penelitian. Populasi penelitian ini adalah seluruh pengusaha kecil dan menengah kripik tempe yang ada di Dusun Sanan Kelurahan Purwantoro Kecamatan Blimbing Kota Malang. Sedikitnya terdapat 272 industri tempe yang ada di Dusun Sanan Kelurahan Purwantoro Kecamatan Blimbing Kota Malang. Sedangkan sampel penelitian menurut Arikunto (2006) adalah sebagian atau wakil populasi yang akan diteliti. Pada penelitian ini, metode pengambilan sampel dilakukan dengan cara purposive sampling. Dalam purposive sampling elemen-elemen yang dimasukkan dalam sampel dilakukan sengaja, dengan catatan bahwa sampel tersebut representatif atau mewakili populasi. Sampel penelitian berjumlah 30 perusahaan atau $11 \%$ dari jumlah populasi dengan kriteria responden sebagai berikut: a) Usaha mikro yang memiliki jumlah tenaga kerja berkisar antara 1 - 4 orang, sejumlah 18 usaha, b)Usaha kecil yang memiliki jumlah tenaga kerja berkisar antara 5 - 19 orang, sejumlah 12 usaha. 


\section{Operasional Variabel}

Variabel dalam penelitian terdiri dari penjualan, jumlah produksi, harga, modal, lama usaha, dan jumlah tenaga kerja. Penjualan adalah total pemasukan yang diperoleh dari penjualan sebelum dikurangi biaya yang dikeluarkan. Jumlah produksi kripik tempe yang dihasilkan per bulan dalam satuan kilogram $(\mathrm{kg})$. Harga merupakan harga jual per kilogram dari setiap produk yang ditawarkan oleh perusahaan. Modal adalah biaya yang dikeluarkan dalam proses produksi dan habis dalam satu kali proses produksi tidak termasuk biaya peralatan. Lama usaha adalah lamanya profesi yang dijalani oleh pengusaha kripik tempe yang dinyatakan dalam tahun. Sedangkan jumlah tenaga kerja adalah jumlah tenaga kerja yang ada saat ini.

\section{Metode analisis Data}

Penelitian ini menggunakan metode analisis cluster yang bertujuan untuk mengelompokkan obyek berdasarkan kesamaan karakteristik diantara obyek-obyek tersebut (Malhotra, 2006). Data mengenai masing-masing perusahaan yang terdiri dari data penjualan, jumlah produksi, harga, modal, dan jumlah tenaga kerja dianalisis untuk melakukan mapping posisi bersaing perusahaan dengan menggunakan matriks posisi bersaing. Dari hasil mapping tersebut akan diketahui di mana posisi bersaing masing-masing, bisa sebagai pemimpin, penantang, pengikut, atau perelung pasar.

Tujuan utama dalam analisis cluster adalah mempartisi suatu set obyek menjadi dua kelompok atau lebih berdasarkan kesamaan karakteristik khusus yang dimiliki. Kelompok atau cluster yang terbentuk merefleksikan struktur yang melekat pada data seperti yang didefinisikan oleh variabel-veriabel.

Metode pengelompokan dalam analisis cluster terdiri dari :

Pertama, Metode Hirarkis. Pada metode ini, pengelompokan dimulai dengan dua atau lebih obyek yang mempunyai kesamaan paling dekat. Kemudian diteruskan pada obyek yang lain dan seterusnya hingga cluster akan membentuk semacam "pohon" dimana terdapat tingkatan atau hirarki yang jelas antar obyek, dari yang paling mirip hingga yang paling tidak mirip. Alat yang membantu untuk memperjeas proses hirarki ini disebut dendogram.

Kedua, Metode Non-Hirarkis. Pada metode ini, pengelompokan dimulai dengan menentukan terlebih dahulu jumlah cluster yang diinginkan (dua, tiga, empat, 
atau yang lain). Setelah jumlah cluster ditentukan kemudian dilakukan proses analisis cluster dengan tanpa mengikuti proses hirarki. Metode ini disebut dengan K-Means Cluster.

Analisis cluster dalam penelitian ini menggunakan metode non-hirarkis atau K-Means Cluster. Jika data yang digunakan memiliki variabilitas satuan maka harus dilakukan proses standarisasi/transformasi data terlebih dahulu dan sebaliknya, jika tidak mempunyai variabilitas satuan maka proses analisis cluster dapat langsung dilakukan tanpa terlebih dahulu melakukan proses standarisasi/transformasi data. Metode analisis cluster dilakukan dengan program SPSS.

\section{Hasil dan Pembahasan}

Industri kripik tempe di Desa Sanan Malang yang merupakan bagian dari UMKM mengalami perkembangan yang cukup baik. Hingga kini berjumlah kurang lebih 386 pengrajin dari total penduduk yang ada di Desa Sanan. 272 pengrajin dari 386 pengrajin tersebut tergabung dalam wadah koperasi produsen kripik tempe Sanan yaitu Primkopti Bangkit Usaha. Koperasi tersebut merupakan wadah bagi para pengrajin, baik pengrajin tempe maupun pengrajin keripik tempe. Namun, koperasi tersebut hanya mengurusi masalah pasokan kedelai, bukan masalah pemasaran.

Responden dalam penelitian ini adalah para pengrajin kripik tempe di Dusun Sanan sebanyak 30 orang terdiri dari 22 orang laki-laki dan 8 orang perempuan. Tingkat pendidikan responden bervariasi mulai dari tamat SD sebanyak 14 orang, SMP sebanyak 11 orang, dan SMA sebanyak 5 orang. Berdasarkan jumlah tenaga kerja yang dimiliki oleh perusahaan rata-rata memiliki jumlah tenaga kerja berkisar antara 1-4 orang. Dari hasil penelitian menunjukkan bahwa perusahaan yang memiliki jumlah tenaga kerja berkisar antara 1-4 orang sebanyak 18 perusahaan yang digolongkan sebagai usaha mikro, sedangkan perusahaan yang memiliki jumlah tenaga kerja berkisar antara 5-19 orang sebanyak 12 perusahaan yang digolongkan sebagai usaha kecil.

Mengenai sumber modal yang dimiliki oleh perusahaan diketahui bahwa sebanyak 27 perusahaan atau $90 \%$ dari total perusahaan menggunakan modal dari kekayaan pribadi atau modal sendiri, dan sebanyak 3 perusahaan atau sebesar $10 \%$ 
masih menggunakan modal yang berasal dari pinjaman. Besarnya modal masingmasing perusahaan antara lain di bawah Rp. 5 juta sebanyak 3 perusahaan, Rp. 5 juta-Rp. 10 juta sebanyak 10 perusahaan, dan di atas 10 juta sebanyak 17 perusahaan. Lama usaha responden dibagi menjadi tiga yaitu, 4-8 tahun sebanyak 16 orang, 5-13 tahun sebanyak 8 orang, dan diatas 14 tahun sebanyak 6 orang.

Tingkat produksi 125-300 kg sebanyak 13 perusahaan, 301-476 kg sebanyak 7 perusahaan, 477-652 kg sebanyak 7 perusahaan, dan diatas $653 \mathrm{~kg}$ sebanyak 3 perusahaan. Sedangkan harga jual yang ditawarkan juga bervariasi yaitu di bawah Rp. 50.000/kg sebanyak 7 perusahaan, Rp. 25.000-Rp. 30.000/kg sebanyaak 21 perusahaan, dan di atas Rp. 30.000/kg sebanyak 2 perusahaan. Data mengenai hasil penjualan di bawah Rp. 5 juta sebanyak 7 perusahaan, Rp. 5 juta-Rp. 10 juta sebanyak 12 perusahaan, dan di atas Rp. 10 juta sebanyak 11 perusahaan.

Karena data yang digunakan memiliki variabilitas satuan maka dilakukan proses standarisasi/transformasi data terlebih dahulu. Setelah itu baru dilakukan proses analisis cluster.

Hasil analisis cluster dijelaskan sebagai berikut :

Tabel 1. Iteration History

\section{Iteration Histor $\hat{y}$}

\begin{tabular}{|l|r|r|r|r|}
\hline \multirow{2}{*}{ Iteration } & \multicolumn{4}{|c|}{ Change in Clus ter Centers } \\
\cline { 2 - 5 } & 1 & \multicolumn{1}{|c|}{2} & \multicolumn{1}{c|}{3} \\
\hline 1 & .000 & 2.245 & 1.661 & 2.006 \\
2 & .000 & .219 & .308 & .172 \\
3 & .000 & .158 & .000 & .206 \\
4 & .000 & .000 & .000 & .000 \\
\hline
\end{tabular}

a. Convergence achieved due to no or small change in cluster centers. The maximum absolute coordinate change for any center is .000 . The current iteration is 4 . The minimum distance betw een initial centers is 4.456 .

Berdasarkan tabel 1 di atas diketahui bahwa untuk mendapatkan cluster yang tepat, proses clustering yang dilakukan melalui 4 tahapan iterasi dengan jarak minimum antar pusat cluster yang terjadi dari hasil iterasi adalah 4, 456.

Tabel 2. Final Cluster Centres

\section{Final Cluster Centers}




\begin{tabular}{|l|c|c|c|c|}
\hline \multirow{2}{*}{} & \multicolumn{4}{|c|}{ Cluster } \\
\cline { 2 - 5 } & 1 & \multicolumn{1}{c|}{2} & \multicolumn{1}{c|}{3} & \multicolumn{1}{c|}{4} \\
\hline Zscore(PENJUAL & 4.10824 & -.41930 & .54251 & -.19123 \\
A) & & & & \\
Zscore(PRODUK & 4.27863 & -.45950 & .60375 & -.19276 \\
SI) & & & & \\
Zscore(HARGA) & -1.34694 & .49784 & -.30662 & -.32852 \\
Zscore(MODAL) & 2.73673 & -.78997 & .37274 & .52965 \\
Zscore(LAMA) & -.45772 & -.57960 & 1.56683 & -.14084 \\
Zscore(TK) & 2.24829 & -.55279 & -.37242 & .71724 \\
\hline
\end{tabular}

Output final cluster centres tersebut masih terkait dengan proses standarisasi data sebelumnya, yang mengacu pada z-score dengan ketentuan sebagai berikut : 1) Nilai negatif (-) berarti data berada di bawah rata-rata total, 2) Nilai positif $(+)$ berarti data berada di atas rata-rata total

Tabel 2 dapat didefinisikan sebagai berikut : Cluster 1 terdiri dari perusahaan atau usaha yang mempunyai jumlah penjualan, jumlah produksi, jumlah modal, dan jumlah tenaga kerja di atas rata-rata. Sedangkan harga dan lama usaha di bawah rata-rata. Dengan demikian maka dapat disimpulkan bahwa cluster 1 merupakan pengelompokan dari perusahaan yang termasuk kategori pemimpin pasar (leader) dicirikan dengan jumlah penjualan, jumlah produksi, jumlah modal, dan jumlah tenaga kerja di atas rata-rata.

Cluster 2 terdiri dari perusahaan atau usaha yang mempunyai harga di atas rata-rata sedangkan jumlah penjualan, jumlah produksi, jumlah modal, lama usaha, dan jumlah tenaga kerja di bawah rata-rata. Dengan demikian maka dapat disimpulkan bahwa cluster 2 merupakan pengelompokan dari perusahaan yang termasuk kategori penceruk pasar (nicher).

Cluster 3 terdiri dari perusahaan atau usaha yang mempunyai jumlah penjualan, jumlah produksi, jumlah modal, dan lama usaha di atas rata-rata, sedangkan harga dan jumlah tenaga kerja di bawah rata-rata. Dengan demikian 
maka dapat disimpulkan bahwa cluster 3 merupakan pengelompokan dari perusahaan yang termasuk kategori penantang pasar (challenger).

Cluster 4 terdiri dari perusahaan atau usaha yang mempunyai jumlah modal dan jumlah tenaga kerja di atas rata-rata sedangkan jumlah penjualan, jumlah produksi, harga, dan lama usaha di bawah rata-rata. Dengan demikian maka dapat disimpulkan bahwa cluster 4 merupakan pengelompokan dari perusahaan yang termasuk kategori pengikut pasar (follower).

Tabel 3. Hasil ANOVA

ANOV A

\begin{tabular}{|l|r|r|r|r|r|r|}
\hline & \multicolumn{2}{|c|}{ Cluster } & \multicolumn{2}{c|}{ Error } & \multicolumn{1}{c|}{} \\
\cline { 2 - 7 } & Mean Square & df & Mean Square & \multicolumn{1}{c|}{ df } & \multicolumn{1}{c|}{ S } \\
\hline Zscore(PENUUALA) & 7.098 & 3 & .296 & 26 & 23.952 & .000 \\
Zscore(PRODUKSI) & 7.870 & 3 & .207 & 26 & 37.965 & .000 \\
Zscore(HARGA) & 2.227 & 3 & .858 & 26 & 2.594 & .074 \\
Zscore(MODAL) & 6.414 & 3 & .375 & 26 & 17.088 & .000 \\
Zscore(LAMA) & 6.502 & 3 & .365 & 26 & 17.803 & .000 \\
Zscore(TK) & 5.001 & 3 & .538 & 26 & 9.291 & .000 \\
\hline
\end{tabular}

The F tests should be us ed only for descriptive purposes because the clusters have been chosen to maximize the differences among cases in different clusters. The observed significance levels are not corrected for this and thus cannot be interpreted as tests of the hypothes is that the cluster means are equal.

Nilai F dan nilai probabilitas (sig) masing-masing variabel digunakan untuk melihat nilai perbedaan variabel pada cluster yang terbentuk. Semakin besar nilai F dan (sig < 0,05), maka semakin besar perbedaan variabel pada cluster yang terbentuk. Berdasarkan tabel 3 di atas maka diketahui bahwa perbedaan variabel pada cluster yang terbesar ada pada jumlah produksi dengan nilai F sebesar 37,965 dan sig $=0,00$.

Tabel 4. Jumlah setiap cluster

lum ber of Cases in each Cluste I

\begin{tabular}{|ll|r|}
\hline Cluster & 1 & 1.000 \\
& 2 & 13.000 \\
& 3 & 6.000 \\
& 4 & 10.000 \\
Valid & & 30.000 \\
Mis sing & & 12.000 \\
\hline
\end{tabular}


Tabel 4 menunjukkan bahwa :

Cluster 1 (pemimpin pasar/market leader)beranggotakan 1 perusahaan atau usaha yaitu usaha tempe yang dimiliki oleh Abdul Majid. Cluster 2 (penceruk pasar/market nicher) beranggotakan 13 perusahaan atau usaha yaitu usaha tempe yang dimiliki oleh Suwono, Kasturi, Bambang, Djumadi, Darto, Laili, Abd. Sholeh, Darmadji, Suci, Priyo, Rokhim, Abdul Rochman, dan Wawan. Cluster 3 (penantang pasar/market challenger) beranggotakan 6 perusahaan atau usaha yaitu usaha tempe yang dimiliki oleh Hasan, Djuari, Kutiya, Priyo, Tumiran, dan Setyowati. Cluster 4 (pengikut pasar/market follower) beranggotakan 10 perusahaan atau usaha yaitu usaha tempe yang dimiliki oleh Choiri, Ema, Maslikah, Gunari, Suparmi, M. Ainur, H. Taufik, Agus, Chifni, dan Hj. R. Jannah.

Dengan demikian maka telah diketahui posisi bersaing masing-masing perusahaan sebagai pemimpin pasar, penceruk pasar, penantang pasar, dan pengikut pasar. Hal ini dapat dijadikan dasar dalam penentuan strategi pemasaran selanjutnya karena strategi pemasaran berbeda pada tiap-tiap posisi.

Perusahaan atau usaha yang termasuk cluster 1 merupakan perusahaan berposisi sebagai pemimpin pasar/market leader. Beberapa strategi pemasaran yang dapat diterapkan oleh pemimpin pasar antara lain : 1, mengembangkan pasar keseluruhan dapat dilakukan dengan mencari pemakai baru, mencari kegunaan baru, penggunaan yang lebih banyak (lebih sering); 2, melindungi pangsa pasar dapat dilakukan dengan pertahanan posisi, pertahanan samping, pertahanan aktif mendahului, pertahanan serang balik, pertahanan bergerak, dan pertahanan penciutan; 3, memperluas pangsa pasar dapat dilakukan dengan keunggulan operasional, kepemimpinan produk, dan keakraban dengan pelanggan.

Perusahaan atau usaha yang termasuk cluster 2 merupakan perusahaan berposisi sebagai penceruk pasar/market nicher. Beberapa strategi pemasaran yang dapat diterapkan oleh penceruk pasar adalah spesialisasi antara lain spesialis pemakai akhir, tingkat vertikal, ukuran pelanggan, pelanggan tertentu, geografis, produk atau lini produk, sifat (karakteristik) produk, pesanan, kualitas atau harga, jasa, dan saluran distribusi.

Perusahaan atau usaha yang termasuk cluster 3 merupakan perusahaan berposisi sebagai penantang pasar/market chalenger. Beberapa strategi pemasaran 
yang dapat diterapkan oleh penantang pasar antara lain : strategi pemotongan harga, strategi produk murah, strategi produk prestise, strategi pengembangbiakan produk, strategi inovasi produk, strategi penyempurnaan layanan, strategi inovasi distribusi, strategi penekanan biaya produksi, dan strategi romosi yang intensif.

Perusahaan atau usaha yang termasuk cluster 4 merupakan perusahaan berposisi sebagai pengikut pasar/market follower. Beberapa strategi pemasaran yang dapat diterapkan oleh pengikut pasar antara lain : cloner yaitu meniru dan menyamai segmen pasar dan bauran pemasaran pemimpin pasar, imitiator yaitu membuat beberapa differensiasi namun tetap meniru pemimpin pasar dalam hal pembaruan pasar dan bauran pemasaran, dan adapter yaitu mencontoh produkproduk pemimpin pasar, memproduksinya namun dengan improvisasi.

\section{Kesimpulan dan Saran}

\section{Kesimpulan}

Berdasarkan hasil penelitian di atas, diperoleh kesimpulan bahwa posisi bersaing UKM produsen kripik tempe di Sanan terbagi menjadi empat cluster atau kelompok yaitu kelompok pemimpin pasar terdiri dari 1 perusahaan, kelompok penceruk pasar terdiri dari 13 perusahaan, kelompok penantang pasar terdiri dari 6 perusahaan, dan kelompok pengikut pasar terdiri dari 10 perusahaan. Setiap perusahaan dapat menerapkan strategi pemasaran sesuai dengan posisi bersaing masing-masing.

\section{Saran}

Saran-saran yang dapat diajukan berdasarkan penelitian ini antara lain produsen kripik tempe harus mengetahui posisi bersaing masing-masing (pemimpin, penceruk, penantang, dan pengikut pasar) sehingga dapat menentukan dan menerapkan strategi pemasaran yang tepat. Bagi peneliti lain yang akan meneliti tentang posisi bersaing UKM disarankan untuk menambah indikator qualitative managerial resources misalnya kekuatan merek, pemasaran, teknologi, kepemimpinan, dan lain-lain. 


\section{DAFTAR PUSTAKA}

Arikunto, Suharsimi. 2006. Prosedur Penelitian Suatu Pendekatan Praktek, edisi revisi, Jakarta: Penerbit PT Rineka Cipta.

Arifin, Daniar. 2000. Analisis Posisi Bersaing untuk Menentukan Strategi Pemasaran Produk Perumahan Eksklusif Puri Ayodya Studi kasus di PT Ayodya Puri Nugraha Semarang. Thesis, Program Pascasarjana Universitas Diponegoro.

Badan Pusat Statistik Jawa Timur. 2011. Jawa Timur dalam angka. jatim.bps.go.id

Dewi, Susi Arfina. 2001. Analisis Penentuan Posisi Bersaing Poliklinik Spesialis Rumah Sakit Umum Palang Merah Indonesia Bogor. http://digilib.ui.ac.id/opac/themes/libri2/detail.... diunduh tanggal 24 April 2011.

Hasan, M. Iqbal. 2003. Pokok-pokok Materi Metodologi Penelitian dan Aplikasinya. Jakarta: Ghalia Indonesia.

Ikhsan, Mohammad, 2004. Mengembalikan Laju Pertumbuhan Ekonomi dalam Jangka Menengah: Peran UKM. Jurnal Analisis Sosial. Vol 9 No. 2 Agustus.

Kotler, Philip dan Kevin Lane Keller. 2007. Manajemen Pemasaran. Edisi 12. Jakarta: PT Indeks.

Kotler, Philip dan Gary Amstrong. 2001. Prinsip-prinsip Pemasaran. Edisi 8. Jakarta: Erlangga.

Malhotra, Naresh K. 2006. Riset Pemasaran Pendekatan Terapan Edisi Keempat Jilid 2. Jakarta: PT. Indeks.

Masyhuri dan Zainudin. 2006. Metode Penelitian. Malang: UIN Press.

Setyawan, Anton A. 2010. Manajemen Usahawan Indonesia. No. 06/TH.XXXIX 2010 Hal 50-55.

Shimaguchi. 2006. Genre of Market Position. Lecture Notes Vol. 7 for Management Strategy.

Tjiptono, Fandy. 2001. Strategi Pemasaran. Edisi II. Yogyakarta: Andi. 